\title{
INTERPRETATION AND UTILIZATION OF AREAL SNOW-COVER DATA FROM SATELLITES
}

\author{
by
}

\section{J. Martinec}

(Swiss Federal Institute for Snow and Avalanche Research, 7260 Weissfluhjoch/Davos, Switzerland)

\section{ABSTRACT}

Areal snow-cover data provided by remote sensing enable the areal water equivalent at the start of the snow melt season to be evaluated. To this end, the time scale in the graphical representation of the snow coverage curves is replaced by the totalized computed daily melt depths. These refer to the seasonal snow cover at the starting date and disregard subsequent snowfalls.

\section{INTRODUCTION}

Since the beginning of Earth satellite observations, snow cover monitoring has been a primary remote sensing objective. In recent years, measurement of the areal extent of snow cover has improved through better spatial resolution and discrimination between snow and clouds. An interpretation of these measurements is required to produce meaningful snow information.

\section{SNOW-COVER MAPPING}

Conventional depletion curves of snow-covered areas in mountain basins are useful for those snow-melt run-off models which are designed to use this information. The shape of these curves, varying from year to year, has even been used to estimate the accumulation of snow in terms of the water equivalent (Meier 1973; Ødegaard and Østrem 1977; Rango and others 1977; Moravec and Danielson 1980). Fig.1 shows, however, that substantial errors may be

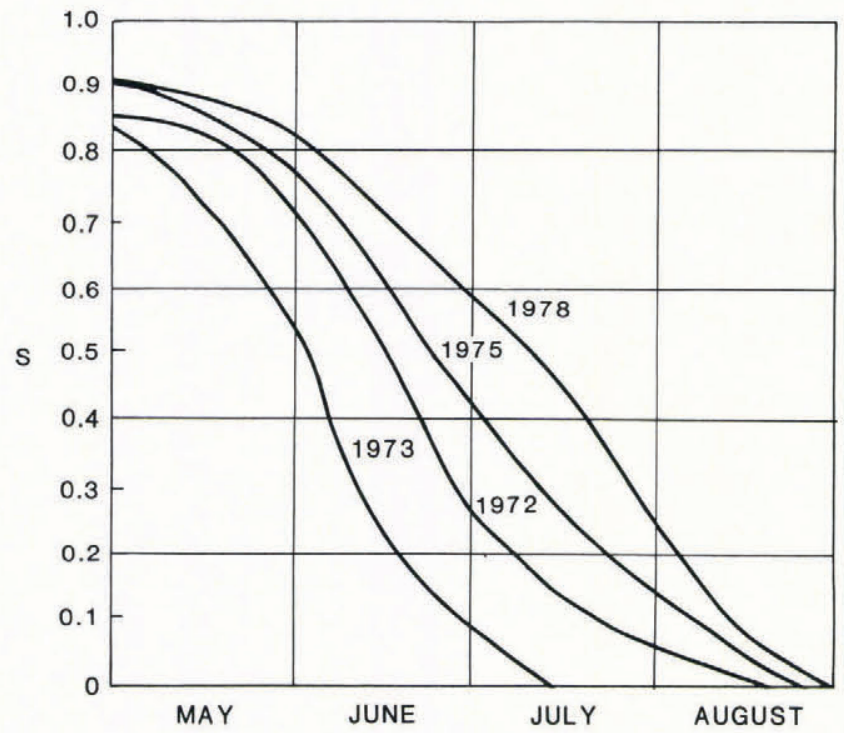

Fig.1. Conventional depletion curves of snow-covered areas in the elevation zone $2100-2600 \mathrm{~m}$ a.s.1. $\left(24.5 \mathrm{~km}^{2}\right)$ of the Dischma basin, Swiss Alps. $S=$ proportion of the snow-covered area. involved. From the depletion curves it would seem that the highest snow accumulation occurred in 1978 and the lowest in 1973, with average values in 1975 and 1972. On the contrary, from direct measurements, the extremes were in 1975 and 1972, with about three times more snow on 1 May 1975 than on 1 May 1972. The course of depletion curves is influenced by weather conditions during the snowmelt season as explained elsewhere (Hall and Martinec 1985).

\section{MODIFIED DEPLETION CURVES OF SNOW COVERAGE}

The snow-covered area declines not because time elapses, but because snow is melting. Modified depletion curves can be derived by replacing the time scale by cumulative melt depths from daily computed values. As shown in Fig.2, these curves represent the snow accumulation in the selected years in the right order and even, especially with regard to 1975 and 1972, in the right proportion. Since the water equivalent at the starting date of the snow-melt season is required, the effect of subsequent snowfalls must be eliminated. Therefore, the energy input required to melt the intermittent new snow is disregarded in calculating the cumulative melt depths. As illustrated in Fig.2, irregularities in the shape of some curves occur due to interpolation problems with the original conventional curves.

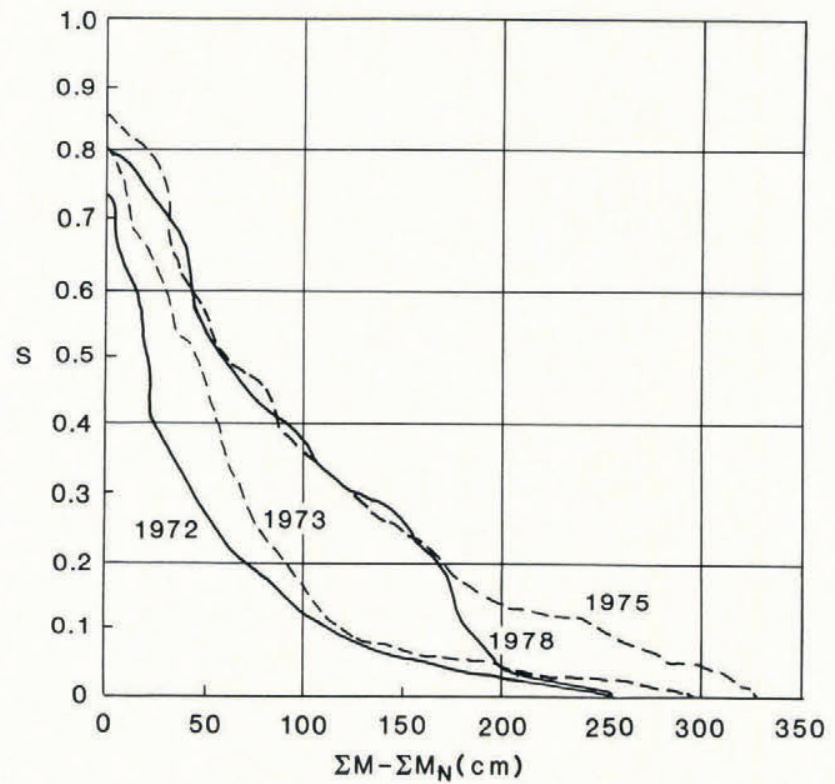

Fig.2. Modified depletion curves of snow-covered areas in the elevation zone $2100-2600 \mathrm{~m}$ a.s.l. of the Dischma basin, Swiss Alps. $\Sigma \mathrm{M}-\Sigma \mathrm{M}_{\mathrm{N}}=$ cumulative snow-melt depth excluding snowfalls after 1 May. 
The interpretation of the modified depletion curves in terms of the water volume stored in the snow cover or, in other words, of the areal water equivalent, is illustrated in Fig.3. These values are directly proportional to the area between the $x, y$ axes and the curve. The results in the given example refer to 1 May, but any other date can be selected for evaluation according to the climate in the investigated basin or partial area.

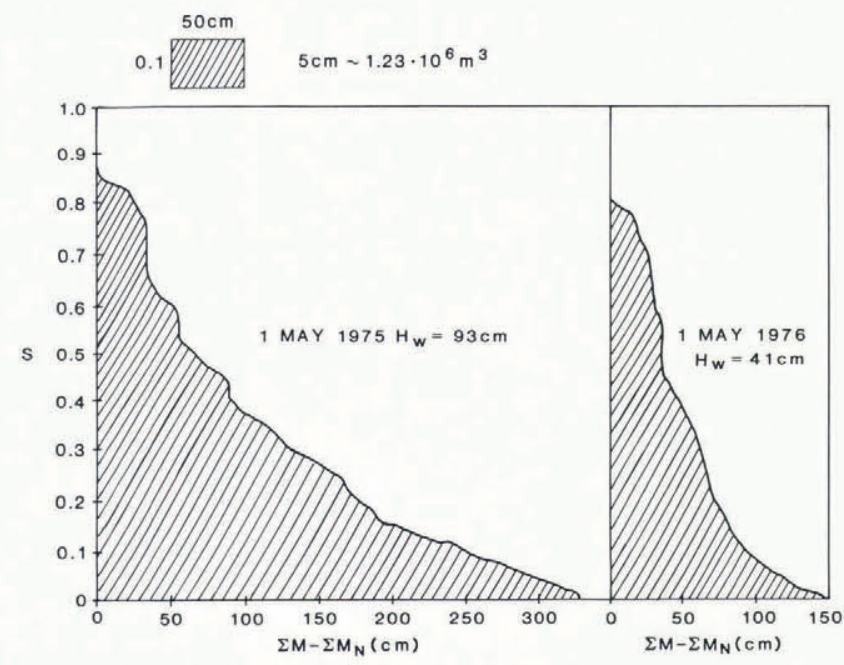

Fig.3. Areal water equivalent from modified depletion curves in two extreme years, zone $2100-2600 \mathrm{~m}$ a.s.1. of the Dischma basin.

\section{EVALUATION OF AREAL WATER EQUIVALENT OF SNOW}

As a verification, the areal water equivalents derived from the modified depletion curves are compared with the point measurements carried out in the period 1970-1979 on 1 May or close to this date. The melt depths were calculated just from the daily maxima and minima of the air temperature (WMO 1986) in order to test the applicability of the method with normally available data and not just in well-equipped representative basins. For the same reason, snowfall in May-August was distinguished from rainfall by a critical temperature although actual observations were available. Modified depletion curves for the elevation zone 1700-2100 m a.s.l. of the Dischma basin and for the four characteristic years are shown in Figure 4. Results are listed in Table I and plotted in Fig.5.

Details of the point measurements are given in the standard data set of Dischma (WMO 1986). Areal water equivalents for the zone $2100-3100 \mathrm{~m}$ a.s.l. are arithmetic

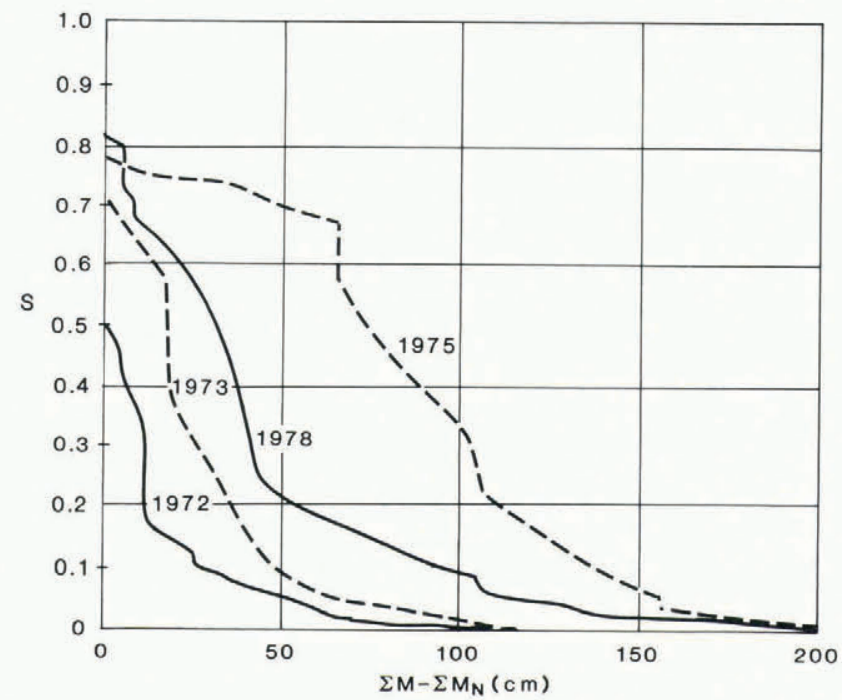

Fig.4. Modified depletion curves of snow-covered area in the elevation zone $1700-2100 \mathrm{~m}$ a.s.l. $\left(8.9 \mathrm{~km}^{2}\right)$ of the Dischma basin.

averages of areal values for the zones $2100-2600 \mathrm{~m}$ a.s.1 and $2600-3100 \mathrm{~m}$ a.s.l. Weighted averages according to the respective areas in the Dischma basin would be about $5-10 \%$ lower.

\section{OPERATIONAL USE OF MODIFIED DEPLETION CURVES}

According to Fig.5, the point measurements at Weissfluhjoch are fairly representative for the elevation zone $2100-3100 \mathrm{~m}$ a.s.l. and the point measurements at the three elevations indicated in Table I for the elevation zone $1700-2100 \mathrm{~m}$ a.s.1. Similarly, the representativeness of selected stations in a snow-gauging network can be evaluated and correction factors derived, if necessary. Thus the operational data measured, for example, for avalanche warning or river flow forecasts can be improved.

Another possible application involves real-time evaluation of the snow accumulation from the modified depletion curves in a current year. However, the processing of satellite images as shown in Fig. 6 and completion of a curve requires time. The accumulation of snow can vary over a wide range from year to year and these variations are revealed by the course of the modified depletion curves of the snow coverage. This is illustrated by Fig.7, in which the curves have been derived from Landsat data. A low accumulation of snow is indicated in 1977 and a high

TABLE I. AREAL WATER EQUIVALENTS $\left(\mathrm{H}_{\mathrm{w}}\right)$ IN THE DISCHMA BASIN COMPARED WITH POINT MEASUREMENTS

\begin{tabular}{|c|c|c|c|c|}
\hline \multirow[b]{2}{*}{$\begin{array}{l}\text { Date: } \\
1 \text { May }\end{array}$} & \multicolumn{2}{|c|}{ Zone $1700-2100 \mathrm{~m}$ a.s.l. } & \multicolumn{2}{|c|}{ Zone $2100-3100 \mathrm{~m}$ a.s.1. } \\
\hline & $\begin{array}{c}\text { Derived } \\
\text { areal } \\
\text { value } \\
\mathrm{H}_{\mathrm{w}}(\mathrm{mm})\end{array}$ & $\begin{array}{l}\text { Average of point } \\
\text { measurements at } 1818 \text {, } \\
1910, \quad 2007 \mathrm{~m} \text { a.s.1. } \\
\mathrm{H}_{\mathrm{w}}(\mathrm{mm})\end{array}$ & $\begin{array}{l}\text { Derived } \\
\text { areal } \\
\text { value } \\
\mathrm{H}_{\mathrm{w}}(\mathrm{mm})\end{array}$ & $\begin{array}{l}\text { Point measurements } \\
\text { at Weissfluh joch, } \\
2450 \mathrm{~m} \text { a.s.1. } \\
\mathrm{H}_{\mathrm{w}}(\mathrm{mm})\end{array}$ \\
\hline 1970 & 552 & 598 & 870 & 1192 \\
\hline 1971 & 129 & 97 & 593 & 621 \\
\hline 1972 & 95 & 90 & 484 & 454 \\
\hline 1973 & 205 & 263 & 665 & 745 \\
\hline 1974 & 304 & 259 & 964 & 987 \\
\hline 1975 & 720 & 561 & 1073 & 1121 \\
\hline 1976 & 169 & 203 & 545 & 493 \\
\hline 1977 & 313 & 406 & 841 & 979 \\
\hline 1978 & 360 & 385 & 847 & 873 \\
\hline 1979 & 478 & 391 & 820 & 814 \\
\hline
\end{tabular}




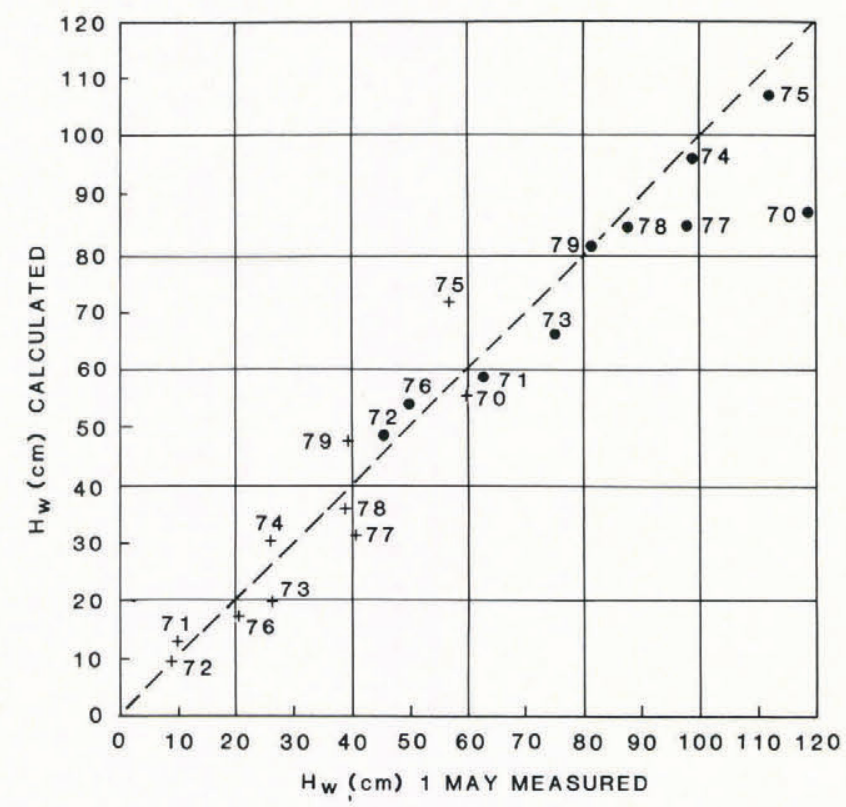

Fig.5. Comparison of areal water equivalents of snow in two elevation zones of the Dischma basin derived from snow-cover mapping and from point measurements at comparable altitudes. $+=1700-2100 \mathrm{~m}$ a.s.1., average elevation $1938 \mathrm{~m}$ a.s.1., and $8.9 \mathrm{~km}^{2}$; $=$ 2100-3100 $\mathrm{m}$ a.s.1., average elevation $2560 \mathrm{~m}$ a.s.1., and $34.4 \mathrm{~km}^{2}$.

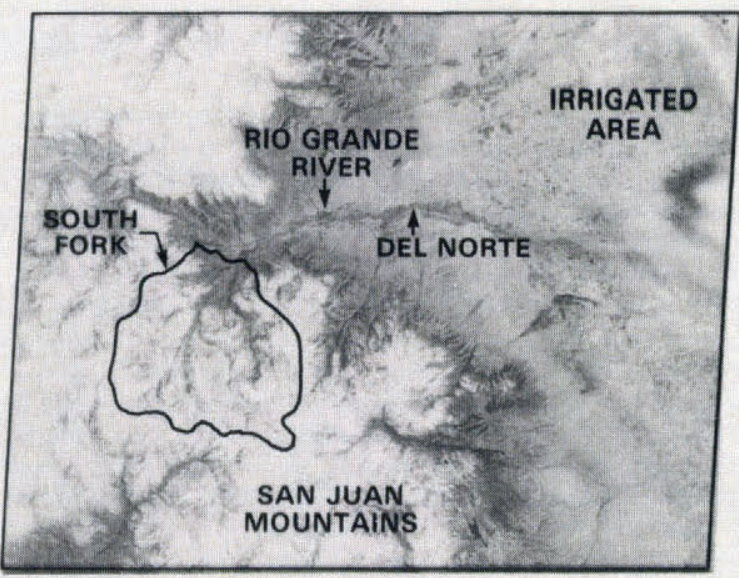

(a)

13 MAY 1979 accumulation in 1979, while the year 1976 represents an average. These conditions are similar in the remaining elevation zones of the South Fork basin and are confirmed by the subsequent run-off volumes. In real time of a future year the problem is how to identify the proper modified curve of the snow coverage as soon as possible after the start of the snow-melt season.

If the snow-covered areas in a basin are available for

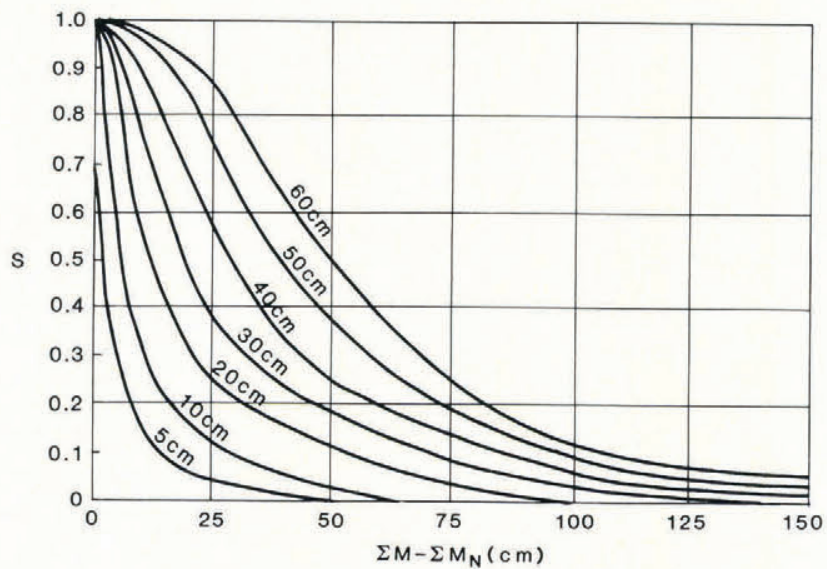

Fig.8. Nomograph for estimating the areal water equivalent of the snow cover on 1 April in the elevation zone 2900-3350 m a.s.l. of the South Fork basin from real-time periodic measurements of the snow coverage and from calculated totalized daily melt depths.

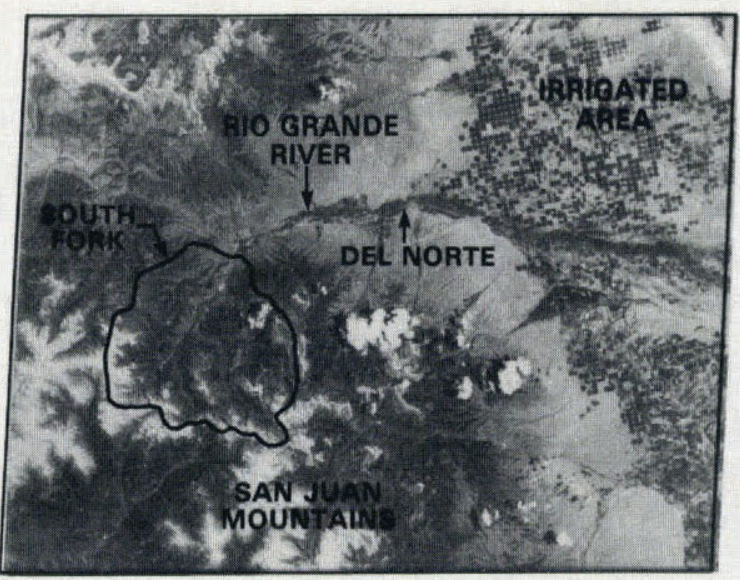

(b)

Fig.6. Landsat $0.6-0.7 \mu \mathrm{m}$ images of the South Fork basin in the Rocky Mountains showing the decrease of the snow-covered area from May to June 1979.

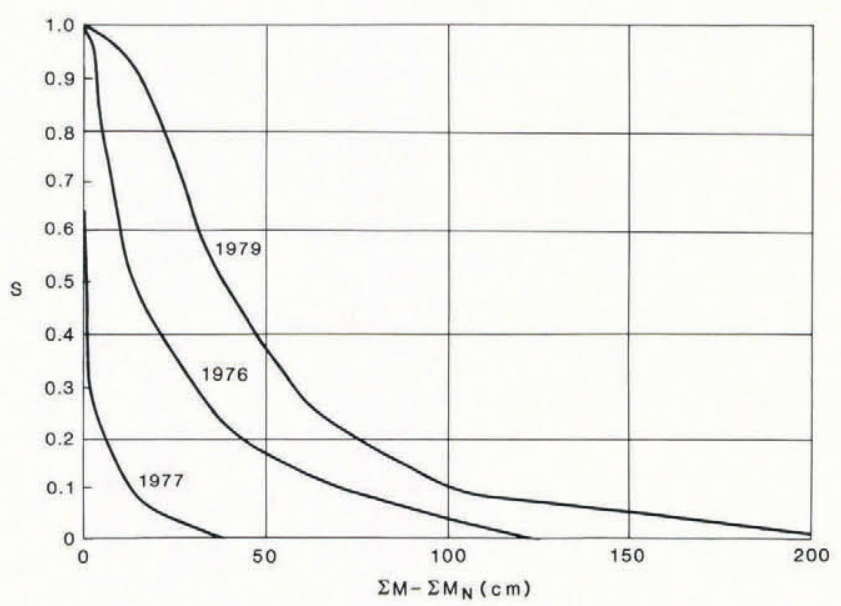

Fig.7. Modified depletion curves of snow-covered area in the elevation zone $2900-3350 \mathrm{~m}$ a.s.1. $\left(269 \mathrm{~km}^{2}\right)$ of the South Fork basin in three characteristic years, starting on 1 April. several snow-melt seasons, preferably including some extreme years, it is possible to draw a set of typical curves, such as the nomograph for the South Fork basin shown in Fig.8. In a future year, snow-water equivalent data such as those available from the SNOTEL system (Rallison 1981) can be used to select an initial curve of the nomograph to use at the beginning of the snow-melt season. Then the snow-covered areas monitored by satellites and the corresponding snow-melt depths, calculated and totalized daily, either confirm this selection or signal a necessary correction. If no measurements of the water equivalent of snow are available, the proper curve may still be recognized in a month or two. For example, if the snow coverage measured on 1 May ( 1 month after the starting date) is $50 \%$ and the total melt depth, excluding new snow, to date is $25 \mathrm{~cm}$, the point falls between the $30 \mathrm{~cm}$ and $40 \mathrm{~cm}$ curves of the nomograph, indicating an initial water equivalent of snow of $35 \mathrm{~cm}$ as an average for the respective area. However, in a year with an unusual spatial distribution of snow at the end of the accumulation period, deviations from the typified shape of the curves must be expected. If such conditions are indicated, for example, by an unusual prevailing wind direction in the winter months, 
the identification of the proper curve is only provisional and must be verified or updated by subsequent measurements of the snow-covered area.

\section{CONCLUSION}

The modified depletion curves of snow coverage can be derived in basins or elevation zones in which the areal extent of the snow cover is periodically measured by satellites or aircraft during the snow-melt season. Further requirements are temperature data which must be extrapolated from a nearby station and precipitation data. The calculation of snow-melt depths, normally based only on temperature, can be refined if pertinent data are available.

Curves derived for past years from historical data can be used to assess the representativeness of point measurements in snow-gauging networks. This serves, for example, to determine the regional anomalies of the maximum expected snow loads on structures. With a timely evaluation of the satellite imagery, the snow accumulation in the given area at the beginning of a current snow-melt season can be evaluated with a certain delay and then updated after each satellite overflight.

\section{REFERENCES}

Hall D K, Martinec J 1985 Remote sensing of ice and snow. London, Chapman and Hall

Meier M F 1973 Evaluation of ERTS imagery for mapping of changes of snow cover on land and on glaciers. Symposium on Significant Results Obtained from the Earth Resources Technology Satellite-1. New Carrollton, MD, NASA: $863-875$

Moravec G F, Danielson J A 1980 A graphical method of stream runoff prediction from Landsat derived snowcover data for watersheds in the upper Rio Grande basin of Colorado. In Rango $\mathrm{A}$, Peterson $\mathrm{R}$ (eds) Operational Applications of Satellite Snowcover Observations. Proceedings of a final workshop ... at Sparks, Nevada, April 16-17, 1979. Greenbelt, MD, NASA: 171-183 (NASA Conference Publication 2116)

Ødegaard H A, Østrem G 1977 Application of Landsat imagery for snow mapping in Norway. Final report. Oslo, Norwegian Water Resources and Electricity Board

Rallison R 1981 Automated system for collecting snow and related hydrological data in mountains of the western United States. Hydrological Sciences Bulletin 26(1): 83-89

Rango A, Salomonson V V, Foster J L 1977 Seasonal streamflow estimation in the Himalayan region employing meteorological satellite snow cover observations. Water Resources Research 13(1): 109-112

WMO 1986 Intercomparison of models of snowmelt runoff. Geneva, World Meteorological Organization (Operational Hydrology Report 23; WMO Publication 646) 